\title{
Studies on the Cultural and Growth Characteristics of Alternaria alternata, Colletotrichum melongenae and Phomopsis vexans the Causing Fruit Rot of Brinjal
}

\author{
Sanjeev Jakatimath ${ }^{1}$, R.K. Mesta ${ }^{1}$, I.B. Biradar ${ }^{2}$, Sadanand K. Mushrif ${ }^{3}$ \\ and P.S. Ajjappalavar ${ }^{4}$ \\ ${ }^{1}$ Department of Plant Pathology (University of Horticultural Sciences), \\ Bagalkot-587104, Karnataka, India \\ ${ }^{2}$ Department of Agronomy (University of Horticultural Sciences), Arabavi-591307, \\ Karnataka, India \\ ${ }^{3}$ Department of Plant Pathology (University of Horticultural Sciences) \\ Kolar-563101, Karnataka, India \\ ${ }^{4}$ Horticultural Research Station (University of Horticultural Sciences) Devihosur-581110, \\ Haveri, Karnataka, India \\ *Corresponding author
}

\section{A B S T R A C T}

Keywords

Alternaria

alternata,

Colletotrichum

melongenae and

Phomopsis vexans

solid media.

\section{Article Info}

Accepted:

17 May 2017

Available Online:

10. June 2017
Brinjal is one of the important vegetable crops growing in India. Fruit rot brinjal caused by Alternaria alternata, Colletotrichum melongenae and Phomopsis vexans is one of the important diseases of brinjal. Hence, in this investigation, critical growth studies were done to understand the pathogen behaviour. The nutritional studies were taken up to know the best medium required for the growth and sporulation of the all three pathogens. The study revealed that out of nine different solid media tested, potato dextrose agar (PDA), oat meal agar and Sabouraud's agar proved best for mycelial growth and sporulation of the all the three pathogens respectively.

\section{Introduction}

Fruit rot of brinjal caused by A. alternata, $C$. melongenae and Phomopsis vexans is prevalent where brinjal is grown and it is major disease during field, transit and market. The fungus derive food and energy from the substrate upon which they grow in nature, in order to culture the fungus in the laboratory, there is no universal substrate or artificial medium upon which all the fungi can grow and reproduce. Therefore studies were conducted in different suitable media to identify surface medium for the growth and sporulation of pathogens involved in fruit rot of brinjal. 


\section{Materials and Methods}

To find out the suitable medium for the growth and sporulation of the fungi Alternaria alternata, Colletotrichum melongenae and Phomopsis vexans, nine solid media viz., Asthana and Hawker's Agar, cornmeal Agar, Czapeck's dox Agar, oat meal Agar, potato dextrose Agar, Richards Agar, Sabaroud's Agar, and Walk's man Agar, Malt agar were taken for in vitro studies. Inoculated plates were incubated at $25 \pm 1 \mathrm{oC}$ and observations on mycelial growth (radial) and sporulation were recorded on 7th and 15th day after incubation. Best solid medium was used for further studies. Growth on different solid media was determined by measuring the colony diameter along with the two diagonals passing though the centre of colony by excluding initial diameter $(5 \mathrm{~mm})$ of bit and sporulation was recorded by using haemocytometer.

\section{Results and Discussion}

Nutrition plays an important role in growth and sporulation of the fungus. In order to determine basal medium for mycelial growth and sporulation of Alternaria alternata, Colletotrichum melongenae and Phomopsis vexans, nine different solid media were tested in vitro. The mycelial growth and sporulation of the all three pathogens on nine different solid media was studied as described in the material and methods and results are presented in tables 1,2 and 3. The Table 1 revealed that there is significant difference between the media with respect to the growth of Alternaria alternata on 7th and 15th day of inoculation. On 7th day highest mycelial growth was observed in Asthana and Hawker's medium $(64.00 \mathrm{~mm})$ which was on par with potato dextrose agar $(62.66 \mathrm{~mm})$ and significantly superior to all other treatments, corn meal agar $(52.66 \mathrm{~mm})$ and Sabouraud's agar $(52.00 \mathrm{~mm})$ were next best treatments, Walk's man agar $(37.00 \mathrm{~mm})$ recorded the least mycelial growth. On 15th day potato dextrose agar $(84.00 \mathrm{~mm})$ recorded highest mycelial growth of Alternaria alternata followed by Asthana and Hawker's medium (79.45 mm), corn meal agar $(70.26 \mathrm{~mm})$, Sabouraud's agar $(70.05 \mathrm{~mm})$ and Walk's man agar (51.92) recorded least mycelial growth. This is depicted in figure 2 .

With reference to the growth character presented in the Table 1 revealed that fungus grew well on both on synthetic and nonsynthetic media. Potato dextrose agar supported the better sporulation. The next best media found to be Asthana and Hawker's medium followed by oat meal agar and Sabouraud's agar. The sporulation was moderate on the rest of the medium. Colony was dull white with fluffy growth at the centre and regular margin in most of the media.

The Table 2 revealed that there was significant difference between the media with respect to the growth of the Colletotrichum melongenae on 7th day and 15th day of inoculation. Mycelium growth is compact and woody in colour was found on Sabouraud's agar medium. On 7th day highest mycelial growth was observed in oat meal agar (73.00 $\mathrm{mm}$ ) which was significantly different with all other treatments, Sabouraud's agar (62.0 $\mathrm{mm})$ and Czapeck's agar $(52.00 \mathrm{~mm})$ were next best treatments, Walkaman agar (34.00 $\mathrm{mm}$ ) recorded the least mycelial growth which was on par with Richards Agar (38.33 $\mathrm{mm})$. On 15th day oat meal agar recorded the highest mycelial growth $(87.40 \mathrm{~mm})$ followed by Sabouraud's agar $(78.00 \mathrm{~mm})$, corn meal agar $(67.20 \mathrm{~mm})$. This was significantly superior to all other treatments. Potato dextrose agar $(59.60 \mathrm{~mm})$ and Asthana and Hawker's medium $(58.00 \mathrm{~mm})$ were on par with each other. Richard's Agar $(46.85 \mathrm{~mm})$ recorded the least mycelial growth. This is depicted in the figure 3. 
Table.1 Studies on cultural characteristics of Alternaria alternata on different solid media after 15 days of inoculation

\begin{tabular}{|c|c|c|c|c|c|}
\hline \multirow{2}{*}{ Sl. No. } & \multirow{2}{*}{ Medium } & \multicolumn{2}{|c|}{ Radial growth (mm) } & \multirow{2}{*}{ Growth character } & \multirow{2}{*}{ Sporulation } \\
\hline & & $7^{\text {th }}$ day & $15^{\text {th }}$ day & & \\
\hline 1 & Asthana and Hawker's agar & 64.00 & 79.45 & Colony is transparent white at the centre with regular margin & +++ \\
\hline 2 & Corn meal agar & 52.66 & 70.26 & $\begin{array}{l}\text { Colony is transparent, mycelium submerged with compact growth and } \\
\text { highly regular margin }\end{array}$ & ++ \\
\hline 3 & Czapeck's agar & 47.00 & 61.40 & $\begin{array}{l}\text { Colony is transparent, white at centre and margin is wavy, prominent } \\
\text { with dull white in colour }\end{array}$ & + \\
\hline 4 & Malt agar & 42.00 & 61.20 & $\begin{array}{l}\text { Colony is pinkish white with zonation, regular margin with slightly } \\
\text { raised growth }\end{array}$ & + \\
\hline 5 & Oat meal agar & 46.00 & 62.52 & Light greyish colony, smooth growth with regular margin & ++ \\
\hline 6 & Potato dextrose agar & 62.66 & 84.00 & Colony is dull white with fluffy growth at the centre and regular margin & ++++ \\
\hline 7 & Richards agar & 40.33 & 57.40 & $\begin{array}{l}\text { Submerged mycelium, colony is dirty white in colour with compact } \\
\text { growth }\end{array}$ & + \\
\hline 8 & Sabouraud's agar & 52.00 & 70.05 & $\begin{array}{l}\text { Mycelium is compact woody in colour with regular definite margin and } \\
\text { slow growth }\end{array}$ & ++ \\
\hline 9 & Walksman agar & 37.00 & 51.92 & Dirty white colour, regular margin with compact growth & + \\
\hline & $S E m \pm$ & 0.50 & 0.81 & & \\
\hline & $\mathrm{CD}$ at $1 \%$ & 1.51 & 2.42 & & \\
\hline & $\mathrm{CV}$ & 1.77 & 2.33 & & \\
\hline & \multicolumn{3}{|c|}{$\begin{array}{c}+ \\
++ \\
+++ \\
++++\end{array}$} & \multicolumn{2}{|l|}{$\begin{array}{c}\text { Fair } \\
\text { Good } \\
\text { Very good } \\
\text { Excellent }\end{array}$} \\
\hline
\end{tabular}


Table.2 Studies on cultural characteristics of Colletotrichum melongenae on different solid media after 15 days after inoculation

\begin{tabular}{|c|c|c|c|c|c|}
\hline \multirow{2}{*}{$\begin{array}{l}\text { Sl. } \\
\text { No. }\end{array}$} & \multirow{2}{*}{ Medium } & \multicolumn{2}{|c|}{ Radial growth $(\mathrm{mm})$} & \multirow{2}{*}{ Growth character } & \multirow{2}{*}{ Sporulation } \\
\hline & & $7^{\text {thy }}$ day & $15^{\text {th }}$ day & & \\
\hline 1 & $\begin{array}{l}\text { Asthana and Hawker's } \\
\text { agar }\end{array}$ & 44.00 & 58.00 & Colony is bright white, cottony and raised growth with irregular margin. & +++ \\
\hline 2 & Corn meal agar & 42.66 & 67.20 & Colony is dull white with irregular margin. & ++ \\
\hline 3 & Czapeck's agar & 52.00 & 53.40 & $\begin{array}{l}\text { Colony is transparent, white at centre and margin is wavy, prominent with } \\
\text { dull white in colour. }\end{array}$ & ++ \\
\hline 4 & Malt agar & 38.33 & 47.40 & $\begin{array}{l}\text { Colony is bright white, yellowish pigmentation towards margin, cottony } \\
\text { growth with wavy margin. }\end{array}$ & ++ \\
\hline 5 & Oat meal agar & 73.00 & 87.40 & Light greyish colony, smooth growth with regular margin. & ++ \\
\hline 6 & Potato dextrose agar & 42.00 & 59.60 & Colony is white in colour, fluffy growth with highly irregular margin. & ++++ \\
\hline 7 & Richards agar & 38.33 & 46.85 & Colony is bright white, profuse fluffy growth and highly regular margin. & + \\
\hline 8 & Sabouraud's agar & 62.00 & 78.00 & Colony is dull white with cottony and raised growth and margin is regular. & ++ \\
\hline \multirow[t]{4}{*}{9} & Walksman agar & 34.00 & 55.85 & Colony is yellowish white, raised and cottony growth with regular margin. & + \\
\hline & SEm \pm & 0.65 & 0.82 & & \\
\hline & $\mathrm{CD}$ at $1 \%$ & 1.94 & 2.46 & & \\
\hline & $\mathrm{CV}$ & 2.36 & 2.53 & & \\
\hline & \multicolumn{3}{|c|}{$\begin{array}{c}+ \\
++ \\
+++ \\
++++\end{array}$} & \multicolumn{2}{|l|}{$\begin{array}{c}\text { Fair } \\
\text { Good } \\
\text { Very good } \\
\text { Excellent }\end{array}$} \\
\hline
\end{tabular}


Table.3 Studies on cultural characteristics of Phomopsis vexans on different solid media after 15 days after inoculation

\begin{tabular}{|c|c|c|c|c|c|}
\hline \multirow{2}{*}{$\begin{array}{l}\text { Sl. } \\
\text { No. }\end{array}$} & \multirow{2}{*}{ Medium } & \multicolumn{2}{|c|}{ Radial growth (mm) } & \multirow{2}{*}{ Growth character } & \multirow{2}{*}{ Sporulation } \\
\hline & & $7^{\text {th }}$ day & $15^{\text {th }}$ day & & \\
\hline 1 & $\begin{array}{l}\text { Asthana and } \\
\text { Hawker's }\end{array}$ & 21.00 & 37.00 & $\begin{array}{l}\text { Colony is dull white in colour and profused mycelia growth with irregular } \\
\text { margin, concentric rings towards centre. }\end{array}$ & ++ \\
\hline 2 & Corn meal agar & 37.00 & 48.00 & $\begin{array}{l}\text { Colony is whitish brown in colour with concentric rings towards centre, } \\
\text { Mycelium is florescent. }\end{array}$ & ++ \\
\hline 3 & Czapeck's agar & 34.66 & 55.46 & $\begin{array}{l}\text { Colony is dull white in colour and profuse mycelial growth with irregular } \\
\text { margin, concentric rings towards centre. }\end{array}$ & ++ \\
\hline 4 & Malt agar & 51.33 & 70.00 & $\begin{array}{l}\text { Colony is whitish brown in colour with concentric rings towards centre; } \\
\text { Mycelium is abundant with raised growth. }\end{array}$ & + \\
\hline 5 & Oat meal agar & 71.00 & 82.72 & Growth is abundant colony is white, Mycelium is fluorescent. & ++ \\
\hline 6 & $\begin{array}{l}\text { Potato dextrose } \\
\text { agar }\end{array}$ & 41.00 & 61.80 & $\begin{array}{l}\text { Colony is compact and thick, Fluffy with concentric rings, Mycelium } \\
\text { creamy White in colour. }\end{array}$ & + \\
\hline 7 & Richards agar & 53.00 & 67.40 & $\begin{array}{l}\text { Colony is smooth, cottony white in colour with regular margin, thick and } \\
\text { profuse growth. }\end{array}$ & + \\
\hline 8 & Sabouraud's agar & 74.00 & 86.80 & $\begin{array}{l}\text { Colony is milky white in colour with profuse growth, Mycelium is raised } \\
\text { at the centre. }\end{array}$ & ++ \\
\hline \multirow[t]{5}{*}{9} & Walksman agar & 39.00 & 50.00 & $\begin{array}{l}\text { Colony is compact and thick, Fluffy with concentric rings, Mycelium is } \\
\text { White in colour with better sporulation. }\end{array}$ & + \\
\hline & $S E m \pm$ & 0.51 & 0.74 & & \\
\hline & CD@1\% & 1.53 & 2.23 & & \\
\hline & $\mathrm{CV}$ & 1.8 & 2.28 & & \\
\hline & \multicolumn{3}{|c|}{$\begin{array}{c}+ \\
++ \\
+++ \\
++++\end{array}$} & \multicolumn{2}{|l|}{$\begin{array}{c}\text { Fair } \\
\text { Good } \\
\text { Very good } \\
\text { Excellent }\end{array}$} \\
\hline
\end{tabular}




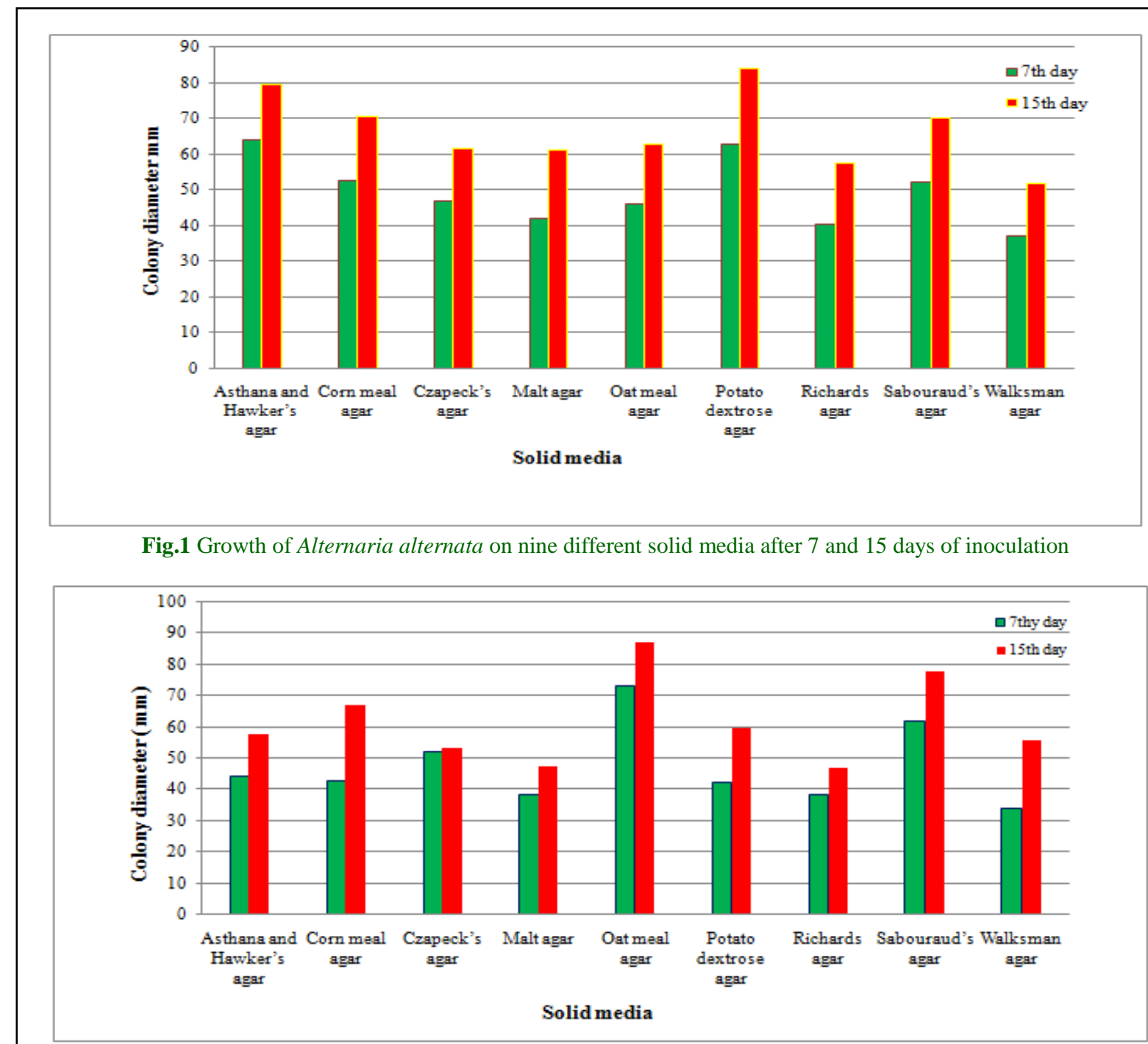

Fig.2 Growth of Colletotrichum melongenae on nine different solid media after 7 and 15 days of inoculation

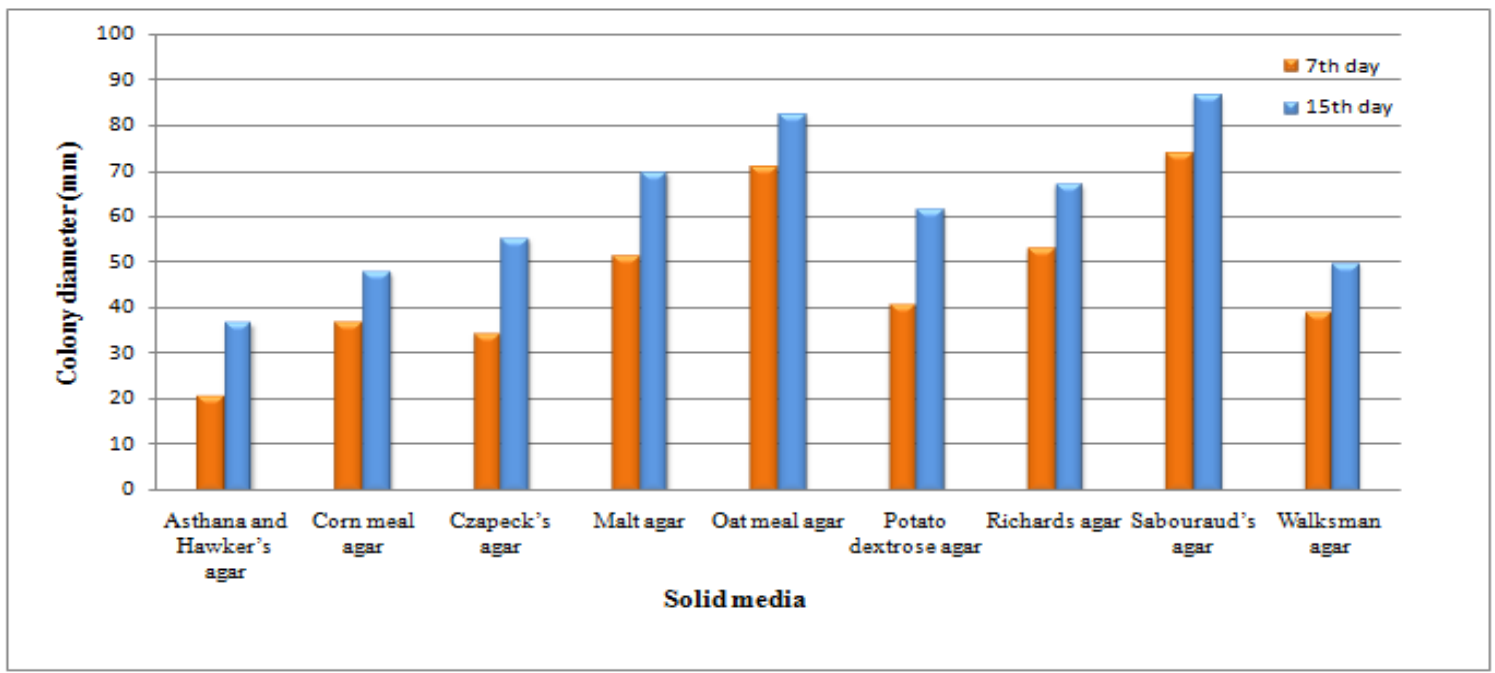

Fig.3 Growth of Phomopsis vexans on nine different solid media after 7 and 15 days of inoculation 
With reference to growth character maximum sporulation was found on potato dextrose agar followed by Asthana and Hawker's, corn meal agar, Cazapek's agar and Sabouraud's agar. It's found that colony on potato dextrose was white in colour and fluffy growth at centre with regular margin. Colony is bright white and raised growth was found on Asthana and Hawker's media and dull white cottony growth on Sabouraud's agar medium.

The table 3 revealed that there was significant difference between the media with respect to the growth of the Phomopsis vexans on 7th day and 15th day of inoculation. On 7th day highest mycelial growth was observed in Sabouraud's Agar $(74.00 \mathrm{~mm})$ which was on par with oat meal agar $(71.00 \mathrm{~mm})$. Richard's Agar $(53.00 \mathrm{~mm})$ and Malt Agar $(51.33 \mathrm{~mm})$ were the next best treatments. Asthana and Hawker's agar recorded the least mycelial growth $(21.00 \mathrm{~mm})$. On 15th day Sabouraud's agar $(86.80 \mathrm{~mm})$ recorded highest mycelial growth which was significantly superior to all other treatments, followed by oat meal agar $(82.72 \mathrm{~mm})$, malt agar $(70.00 \mathrm{~mm})$ and Richard's Agar $(67.40 \mathrm{~mm})$ which were on par with each other. Asthana and Hawker's medium $(37.00 \mathrm{~mm})$ recorded the least mycelial growth. This is depicted in the Fig. 4. Observation in present investigation are in contrary with the results of Ionnsidis and Main (1973) who observed best growth and sporulation of Alternaria alternata on potato dextrose agar followed by oatmeal agar medium. Singh et al., (2001) reported that potato dextrose agar medium supported better mycelial growth and sporulation of Alternaria alternata followed by Richard's medium, Czapeck's dox agar media and Asthana medium. Ram et al., (2007) observed maximum growth and sproulation of Alternaria alternata causing Alternaria fruit rot of ber on potato dextrose agar medium. Saeed et al., (1995) reported that Alternaria grew best on Richard's agar medium. This vatration in growth of fungi in all media is because of composition of different medium and source of carbon utilised by them. For the growth of $A$. alternata, dextrose, maltose and xylose were significant carbon sources (Patil et al., 2015).

Observation in present investigation with respect to mycelial growth and sporulation of Colletotrichum melongenae are in contradictory with the results of Sudhakar et al., (2000) who observed maximum mycelial growth of Colletotrichum spp. on Sabouraud's agar followed by Richards's agar, Browns agar. Rani and Murthy (2004) reported that Richards's agar and Brown's agar medium supported better mycelial growth and sporulation of Colletotrichum gleosporiodes in cashew followed by Richard's medium, corn meal agar medium. Ashoka (2005) reported that maximum radial growth of Colletotrichum gloeosporioides on potato dextrose agar $(90.00 \mathrm{~mm})$ and Richard's agar (90.00 mm). Ekbote (1994) observed that maximum radial growth Colletotrichum spp (90 mm) in Richard's agar and Brown's agar and potato dextrose agar. Hiremath et al., 1993 reported that the pathogenic culture of Colletotrichum gloeosporioides made good, white to greyish mycelial growth with abundant sporulation on Czapek's, host leaf extract, two per cent sucrose, oat meal agar and Richard's agar media. Akthar (2002) reported that the fresh potato extract was the best source for routine isolation and growing Colletotrichum sp. causing mango anthracnose.

Observations of present investigation with respect to the growth and sporulation of Phomopsis vexans are in close conformity with the results of Divinagracia et al., (1969) who reported that Phomopsis vexans produces abundant conidiomata on 4-7\% oat meal agar medium at $30^{\circ} \mathrm{C}$ under light. Because light was needed for abundant sporulation of $P$. vexans and also with that of Harada et al., (1973) who found that formation of Pycnidia 
and spores were dependent on light intensity and temperature while working with P. mail. Also present findings are in line with the finding of Ekbote (1994) in case of C. gloeosporioides and Hiremath et al., (1993) in case of C. gloeosporioides causing Shisham blight. However Stefaniak et al., (2012) who recorded the growth of Phomopsis vexans on different media found that PDA and Czapek-Dox media were considered as the most suitable for diagnostic purposes due to the formation of characteristic macroscopic and microscopic features on these substrates. WU Ren-feng et al., (2013) showed that the optimum culture medium for mycelial growth was potato dextrose agar.

\section{References}

Ashoka, S. 2005. Studies on fungal pathogens of vanilla with special reference to Colletotrichum gloeosporioides (Penz.) Penz. And Sacc. M.Sc. (Agri.) Thesis, Uni. Agric. Sci., Dharwad, India.

Devingracia, G.G. 1969. Host penetration, requirements for in vitro growth. Philipp Agric., 53: $173-185$.

Ekbote, S.D. 1994. Studies on anthracnose of mango (Mangifera indica L.) caused by Colletotrichum gloeosporioides (Penz.) Penz. And Sacc. M.Sc (Agri.) Thesis, Uni. Agric. Sci. Dharwad, India.

Harada, Y., Terul J.V.L., Kuwata, H., Suzuki, S. and Fugita, T. 1973. Effect of light and temperature on pycnidial and pycnospore formation in Phomopsis moil Bulletin of the Faculty of agriculture, Hirosaki Uni., 18: 140-151.

Hiremath, S.V., Hiremath, P.C. and Hedge, R.K. 1993. Studies on cultural characters of Colletotrichum gloeosporioides a causal agent of Shisham blight. Kar. J. Agric. Sci., 6: 30-32.
Ionnidis, N.M. and Main, G.C. 1973. Effect of culture medium on production and pathogenecity of Alternaria alternata. Pl. Dis. Rep., 57(1): 39-42.

Patil, J.S. and N.S. Suryawanshi. 2015. Effect of nutritional and physiological characters of Alternaria alternata causing fruit rot of strawberry. Res, Lab, Dept, Bota, K.V. Pendharkar College of Arts, Science and Commerce, Dombivli (E)- 421203 Maharashtra (India). 8 (1):69.

Rani, S.G. and Murthy, K.V.M.K. 2004. Cultural and nutritional characteristic of Colletotrichum gloeosporioides, the causal organism in cashewnut anthracnose. J. Mycol. Pl. Path., 34: 317-318.

Saeed, M., A. Ahmad, M. and Khan, M. A., 1995, Effect of different media, temperature, $\mathrm{pH}$ levels, nitrogen and carbon sources on the growth of Alternaria alternata. Pak. J. Phytopath., 7(2): 210-211.

Singh, J. and Majumdar, V.L. 2001. Efficacy of plant extract against Alternaria alternata. The incitant of fruit rot of pomegranate (Punica granatum L). J. Mycol. Pl. Path., 31(3): 346349.

Stefaniak, M., Z.E., Król, E. and Kowalik, B. 2012. Growth and development of Phomopsis diachenii Sacc. In different culture conditions Acta Sci. Pol. Hortorum Cultus., 11(6): 69-80.

Sudhakar. 2000. Biology and management of Stylosanthes anthracnose caused by Colletotrichum gloeosporioides (Penz.) Penz. And Sacc. M.Sc (Agri.) Thesis, Uni. Agric. Sci. Dharwad, India.

Ren-feng, W.U., Yang Shao-li. and Yang De-zhi. 2013. Studies on identification of eggplant Phomopsis rot caused by Phomopsis vexans and its biological characteristics Wuhan Vegetable Research Institute Wuhan 430065, Hubei, China, 1(8): 80-85.

\section{How to cite this article:}

Sanjeev Jakatimath, R.K. Mesta, I.B. Biradar, Sadanand K. Mushrif and Ajjappalavar, P.S. 2017. Studies on the cultural and growth characteristics of Alternaria alternata, Colletotrichum melongenae and Phomopsis vexans the causing fruit rot of brinjal. Int.J.Curr.Microbiol.App.Sci. 6(6): 1062-1069. doi: https://doi.org/10.20546/ijcmas.2017.606.122 